\title{
日本人類遺伝学会第 23 回大会記事（1978） \\ Proceedings of the 23rd Annual Meeting of the Japan Society of Human Genetics, 1978
}

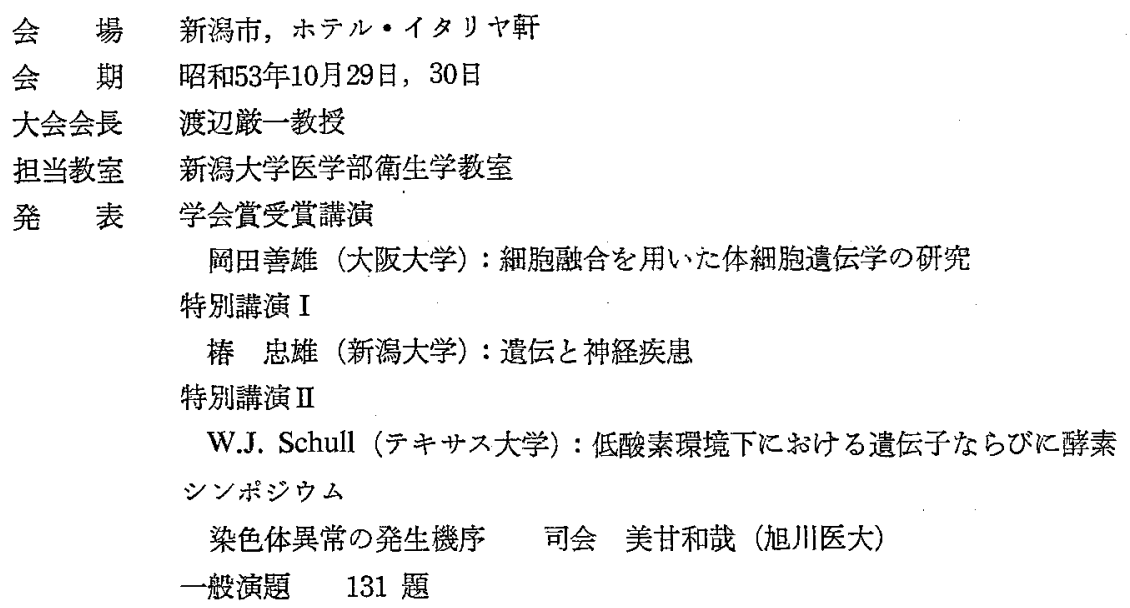

第 1 日（10月29日）

渡辺大会会長の開会の辞につづき，午前には一般演題51題が発表された. 午後は総会議事にはじ

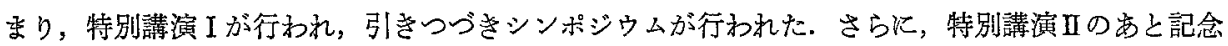
撮影があり，柧親会が開かれた。

第2 日（10月30日）

午前中に一般演題 41 題が発表され，午後注学会賞の受賞式，同受賞講演が行われ，引りきづきー 般講演39題が発表された。

\section{評議 員会}

日 時: 昭和53年10月28日, $18: 30 \sim 20: 30$

場 所：ホテル・イタリヤ軒

出席者 : 34名, 議長は井上英二会長

1. 報告事項

庶務, 会計, 編集についての会務経過について報告が西ったのち，学会賞選考委員会，造伝相談ネ ットワーク委員会, 教育委員会, 日本医学会評議員会, 日本学術会議 IUBS 研究連絡委員会遗伝分科 会, 国際人類遗伝学会議常置委員会, 国際遺伝学連合, 遺伝子操作委員会, 科学研究費閣題等につい て報告がなされた。 


\section{2. 㙝議事項}

（1）会費值上げの件

学会財政状況逼迫の折から，一般会費を年額3,000円上り5,000円に値上げすることが承認された。 それにとすない，外国人会員汶する会費を円建てとすることが了承された。

（2）次々期大会開催地と大会会長の件

昭和55年度大会開催地は仙台とし，多田啓也東北大学教授を推薦すること決定した。

(3) 名誉会員辣萀の件

名誉会員として，別記 5 名の方を推薦することを決定した（総会記事に記戴の通りである）.

(4) 理事補充の件

井上前理事の会長就任飞ともない，理事の補充について慎重審議の結果，理事選挙の折，次点者 であった外村評議員を新理事として推萀すること苋決定した。

\section{総 会議 事}

A. 報告事項

1) 庶務報告 (日暮幹事)

a）会員の異動

昭昭52年12月 31 日現在，本会会員数と異動性下記の通りである.

\begin{tabular}{|c|c|c|c|c|}
\hline & \multirow{2}{*}{ 現在数 } & \multicolumn{3}{|c|}{ 昭和52年度異動 } \\
\hline & & 入会 & 退会 & 增 \\
\hline 普通会員 & 864 & 80 & 52 & 28 \\
\hline 名誉会量，国外 & 14 & 2 & 0 & 2 \\
\hline 确云兒（国内 & 8 & 2 & 0 & 2 \\
\hline 外国会員 & 6 & 3 & 1 & 2 \\
\hline 計 & 892 & 87 & 53 & 34 \\
\hline
\end{tabular}

b) 理 事 会

昭和53年 9 月30日と同年10月28日の計 2 回開催された.

2）会計報告（外村幹事）

昭和52年度の会計報告は次の表の通りである.

\begin{tabular}{|c|c|c|c|}
\hline 収 入 & 部 & 支 出 & の \\
\hline 前年度繰越金 & $3,707,727$ 円 & 雑誌刊行費 & $3,146,354$ 円 \\
\hline 会費 & $2,258,000$ & 雑誌発送費 & 276,456 \\
\hline 諭文掲載料 & 940,275 & 雑誌編集費 & 107,000 \\
\hline 雑誌購読料 & 280,500 & 大会補助金 & 300,000 \\
\hline 広告料 & 52,500 & 事務費 & 444,830 \\
\hline 文部省科研費補助金 & 880,000 & 次年度繰越金 & $3,961,737$ \\
\hline 医師会劰成金 & 100,000 & & \\
\hline 預金利子 & 17,375 & & \\
\hline 計 & $8,236,377$ & 訪 & $8,236,377$ \\
\hline
\end{tabular}


3）監查報告（藤木理事）

上記の会計報告に誤りない旨報告された。

4) 編集委員会（岡島編集委員長）

雑誌の刊行状況について報告された。

5) 遺伝相談ネットワーク委員会 (半田委員長)

今後の活動にりいて検討中である.

6) 人類遺伝教育委員会 (三輪委員長)

昭和52年11月12日第 1 回委員会を開き, 各委員の業務分担を決めた後, 本邦各医科大学, 医学 部内にて行われている「人類遺伝学」に関する教育の実態状洗の調查, 欧米諸国での医学教育の 中に䑙ける人類遺伝学カリキニラムの資料収集等の活動を現在行いつつある旨，報告があった。

7) 日本学術会議 IUBS 研究連絡委員会遺伝分科会 (岡島理事)

日本学術会議第11期の活動の中に医学教育になける遺伝学の問題を取り上げることとなり，本 学会の教育委員会と逨絡をとりながら检討を進めることになった。 また，アメリカ遗伝学会から， 遗伝学に関する historical materials の保存について申入れがあったので，日本遺伝学会が中心 になって考えることになった。

8）日本医学会評議員会 (中島理事)

日本医学会総会の進行状況等について報告が施った。

9) 国際人類遺伝学会議常置委員会 (井上会長)

次回の国祭人類遺伝学会は，1981年 9 月13日より20日宗で，エルサレムにて開催されることが 決定した旨報告があった。

10）国際遗公学要合（岡島理事）

第14回国際遺伝学会議心，昭和53年 8 月にモスコーで開催された。次の会議は1983年にインド で開かれる。

11）学会賞選考委員会（井上会長）

HVJ を用いた紐胞融合の発見，色素性乾皮症の細胞学的研究によって，わ分国捻よび世界の 人類遺伝学の発展に貢献した岡田善雄氏に贈呈することに決定した旨，報告が殅った。

12）遗伝子操作委員会 (井上会長)

別項記載のように，新たに遺伝子操作㙝議会（仮称）が発足するにとるない，本学会より外村 晶教授を委員として推䳡し，分担金を負担することになった。

13）次期大会（并上会長）

次期大会は，昭和54年11月 3 日，4 日，5日，日本都市せンターにて開催される旨，報告があ った。

B. 承認事項

1）会費值上げの件

一般会員会費は年額3,000円より5,000円に変更すること，ならびに外国人会員の会費は円建て とすることが提案され，承認された。

2）次々期大会飞関与る件

䀡和 55 年度大会開催地は仙台とし，東北大学の多田啓也教授を大会会長とすることが承認され た.

3）名誉会員の件

吉川秀男氏，鉿木安恒氏，藤井祐一氏，高原滋夫氏，ならびに村上氏広氏を第 $27 ， 28 ， 29 ， 30$ ， 
31人目の国内名誉会員に推萀することが提案され，承認された。

4) 理事補充の件

并上前理事の会長就任にとるない，欠員となった理事の補充に関し慎重審議の結果，理事選挙 の折，次点者で方った外村晶評議員 (会計担当幹專) 飞新理事化補らことが提案され，承認された。 な䍄，外村会訫幹事の理事就任により，当分の間外村理事が会計幹事を兼任することも承認さ机 光.

理 事 会

日 時：昭和53年10月28日 $16: 00 \sim 18: 00$

場 所 : ホテル・イタリヤ軒（新潟市）

出席者 : 井上英二会長，井関尚栄前会長，渡辺厳一大会会長，岡島道夫・中島章・半田順俊・藤杢典 生各理事, 外村晶・笹月健彦・日暮真各幹事

1. 報告事項

庶務，会計，編集，各種委員会等の報告がなされた．むた，次々期大会会長について多田啓也氏 より内諾が得られた旨報告があった。

2. 協議夢項

理事補充の件，名誉会員の追加の件等について協議がなされれた。 